\title{
KOMPOSISI DAN SEBARAN BURUNG DI HUTAN LINDUNG KPHP SORONG SELATAN DI PAPUA BARAT
}

\section{(Compositions and Distribution of Bird in Protected Forests South Sorong in West Papua)}

\author{
Warsito. H. ${ }^{1}$, L. Khayati ${ }^{1} \&$ Y. Komendi ${ }^{1}$ \\ ${ }^{1}$ Balai Penelitian dan Pengembangan Lingkungan Hidup dan Kehutanan Manokwari \\ Jl. Inamberi, Susweni Po. Box. 159 Manokwari 98131, Papua Barat \\ Telp. (0986) 213440 Fax. (0986) 213441; 213437; website www.balithutmanokwari.com \\ Email:warsito_17@yahoo.co.id; lisna.biologi@gmail.com; yuskom@yahoo.com
}

\begin{abstract}
KPHP South Sorong is one of the existing protected areas. The composition and distribution of bird species in a protected area can determine the quality and condition of existing forests. The approach of exploratory and population methods is used to determine the diversity of bird species present in the location. From 4 (four) location observations, at least obtained 34 species from 14 families in protected forest area KPHP south Sorong. The condition of degraded forests has an impact on the acquisition of bird species. Birds of the small vertebrate eater group (35\%) dominate this area, compared to the fruiting birds (32\%) and both insects, small vertebrates and fruits (30\%). While high utilization by the community, the impact on the lack of large animals in protected areas KPHP Sorong South West Papua.
\end{abstract}

Keywords: Composition, distribution, birds, protected areas, KPHP and West Papua

\begin{abstract}
ABSTRAK
KPHP Sorong Selatan merupakan salah satu kawasan lindung yang ada. Komposisi dan sebaran jenis burung dalam suatu kawasan lindung dapat mementukan kualitas dan kondisi hutan yang ada. Pendekatan metode jelajah dan populasi digunakan untuk mengetahui kondisi keragaman jenis burung yang ada di lokasi tersebut. Dari 4 (empat) lokasi pengamatan, sedikitnya diperoleh 34 jenis dari 14 famili di kawasan hutan lindung KPHP Sorong Selatan. Kondisi hutan yang terdegradasi memberi dampak pada perolehan jenis burung. Burung dari kelompok jenis pemakan serangga dan vertebrata kecil (35\%) mendominasi di kawasan ini, dibandingkan jenis burung kelompok pemakan buah (32\%) dan gabungan keduanya serangga, vertebrata kecil dan buah (30\%). Sementara adanya pemanfaatan oleh masyarakat yang tinggi, berdampak pada kurangnya satwa yang berukuran besar di kawasan lindung KPHP Sorong Selatan Papua Barat.
\end{abstract}

Kata kunci: Komposisi, sebaran, burung, kawasan lindung, KPHP dan Papua Barat

\section{PENDAHULUAN}

Luas kawasan hutan di Indonesia mencapai 130 juta hektar, dimana terbagi ke dalam hutan konservasi (HK) seluas 26,82 juta ha, hutan produksi (HP) 75 juta ha dan hutan lindung (HL) 28,86 juta ha (Kementerian Kehutanan, 2011). Total luas hutan produksi dan hutan lindung mencapai 103,86 juta ha, pengelolaan hutan oleh pihak swasta berupa IUPHHK hutan alam maupun hutan tanaman. Dikelola oleh masyarakat yaitu hutan tanaman rakyat, hutan kemasyarakatan dan hutan desa serta oleh BUMN melalui Perum Perhutani. Sedangkan yang dikelola oleh Kementerian Kehutanan yakni KPH seluas 16 juta ha. Total kawasan HP dan HL yang sudah dikelola mencapai 53,12 juta ha dan sisanya 50,74 juta ha belum dikelola (Kementerian Kehutanan, 2013). Masyarakat yang memanfaatkan potensi 
kawasan secara langsung tanpa memperhatikan kelestarian sumberdaya alam merupakan persepsi kategori negatif (Sawitri \& Subiandono, 2011). Hutan harus tetap terjaga dan disatu sisi juga bisa bermanfaat, oleh karena itu dibutuhkan pendekatan melalui KPH (Rizal, HB., Dewi, \& Sumedi., 2011). Ada hal yang mendasar untuk membangun KPH. Pertama: aspek kawasan, KPH mampu menjaga dan mempertahankan keberadaan kawasan hutan yang rusak atau tidak dikelola. Kedua, aspek kelembagaan, $\mathrm{KPH}$ harus memperbaiki profesional kehutanan yang rendah. Ini juga dapat memperbaiki institusi di tingkat tapak. Ketiga, aspek perencanaan, KPH dapat mengoptimalkan pengelolaan hutan yang rendah dan memastikan strategi bisnis kehutanan. Namun yang menjadi permasalahan adalah apakah tiga aspek tersebut ada di lapangan (tapak).

Penentuan daerah prioritas konservasi ini dimaksudkan untuk menjaga kelestarian ekosistem dan komponen yang terdapat di dalamnya mengingat semakin terdesaknya ekosistem kawasan hutan yang membuat beberapa jenis satwa dapat terancam kepunahan dari jenis endemik dan memiliki nilai keunikan/morfologis yang memikat dan indah. KPH Sorong Selatan yang berada di Papua Barat adalah satu dari beberapa KPH yang ada di Papua, meskipun belum disahkan berdasarkan Undang-Undang Kehutanan atau Permenhut. Namun kawasan tersebut dimasukan dalam KPH yang penunjukkannya di wilayah KPH model Sorong.

Beberapa kawasan yang menjadi skala prioritas pengelolaan konservasi baik flora maupun fauna di dalamnya diperlukan penanganan seefektif mungkin dan melibatkan masyarakat lokal yang menjadi obyek dan pelaku di daerah tersebut.
Keberadaan fauna yang mendiami kawasan perlu mendapatkan perhatian (Pratiwi, 2005), salah satu adalah burung. Burung merupakan jenis satwa yang dapat dijadikan indikator lingkungan, karena apabila terjadi degradasi lingkungan burung, komponen alam terdekat yang terkena dampaknya (Jamaksari, 2011; Welty, 1982). Komposisi dan sebaran burung di suatu kawasan menjadikan dasar keragaman jenis yang ditemukan (Mendidit, Gunawan, \& Nurhadi., 2003). (Hail, Kavanagh, Kumari, \& Arifin., 1990), rendahnya komposisi dan sebaran jenis burung suatu kawasan, dapat menandakan/ditengarai bahwa habitat yang ada telah terdegradasi atau terfragmentasi. Namun disisi lain, sebagai akibat dari tekanan kebutuhan ekonomi masyarakat dan adanya kepentingan daerah dalam pembangunan yang dapat menjadi faktor terjadinya penurunan populasi jenis.

Data dan informasi mengenai komposisi dan sebaran merupakan bagian dari pendekatan guna melakukan manajemen konservasi bagi satwa burung khususnya. Sehingga upaya perlindungan terhadap burung di kawasan hutan KPHP Sorong Selatan sebagai tempat hidup dan berkembang perlu dilakukan. Dengan demikian dapat dijadikan sebagai acuan dalam penetapan pengelolaan kawasan yang lestari.

\section{METODE PENELITIAN}

\section{A. Waktu dan Lokasi Penelitian}

Lokasi yang digunakan sebagai penelitian adalah kawasan lindung di sekitar kampung Sesor, secara administratif ke dalam wilayah Teminabuan yang merupakan salah satu wilayah KPH model yang berada di Kabupaten Sorong Selatan. 


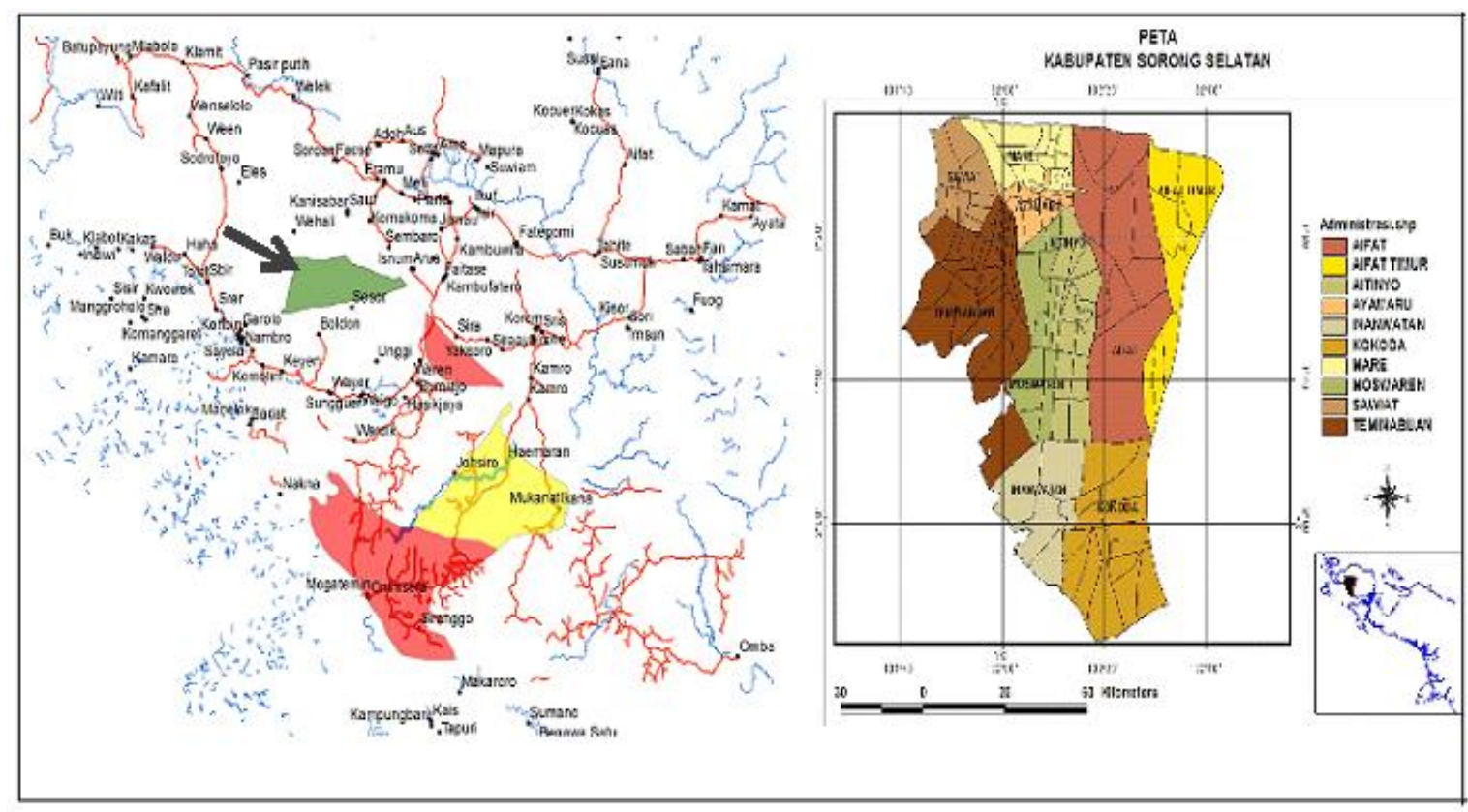

Gambar 1. Lokasi penelitian

Figure 1. Research of location

\section{B. Bahan dan Alat}

Alat yang digunakan berupa; Binocular Tasco 8x75, Caliper, Misnet, Termohigro, GPS Garmin 76 Csx, alat dokumentasi (kamera) dan alat tulis menulis.

\section{Metode Penelitian}

Metode penelitian yang digunakan dalam pelaksanaan penelitian adalah dengan melakukan kombinasi metode dalam pendekatannya, yaitu: Timed Count Species (TSCs) (Bibby., Jones, \& Marsden, 2000) dan Catching (Howes, Bakewell, \& Noor, 2003). Metode TSCs dengan melakukan mencatat semua jenis yang dijumpai di lokasi pengamatan dengan interval waktu selama 20 menit pertama. Pada 20 menit berikutnya mencatat semua jenis yang baru ditemukan dan seterusnya, sehingga akan diperoleh akumulasi jenis burung yang dilakukan di lokasi pengamatan. Pengamatan dilakukan pada waktu puncak aktivitas satwa yaitu pada pukul 06.30-09.30 dan dilanjutkan pada pukul 14.00-17.30 waktu sempat.

Sedangkan metode Catching (Howes et al., 2003), penangkapan burung dengan menggunakan jala kabut (misnet). Pemasangan jala kabut ditempatkan di lokasi yang menjadi jalur atau lintasan bagi burung, seperti sisi atau lereng bukit, sekitar sumber air atau aliran sungai dan atau tepian hutan antara hutan terbuka dengan yang rapat tegakannya. Burung yang tertangkap, diidentifikasi dan diukur/morfometri (untuk melengkapi data bila diperlukan), selanjutnya dilepaskan kembali.

Data yang diperoleh dianalisis dengan menggambarkan persentase komposisi jenis dan kurva akumulasi spesies. Data yang terhimpun dikelompokan dalam beberapa kategori seperti: kehadiran di habitat, kelompok jenis dan jenis yang dimakan/ feeding guilds. Sementara untuk mengetahui status perlindungan dilakukan dengan telaah 
pustaka dengan mengacu beberapa literatur yang ada seperti: Daftar Burung Indonesia 2 (Sukmantoro et al., 2007) dan Jenis-jenis hayati yang dilindungi Perundang-Undangan Indonesia (Noerdjito \& Maryanto, 2007). Sedangkan untuk identifikasi burung menggunakan buku Panduan Lapangan Burung-burung di Kawasan Papua (Behler, Pratt, \& Zimwerman, 2001).

\section{Analisa Data}

Pengolahan dan analisa data meliputi : penyusunan daftar burung di lokasi pengamatan, keragaman jenis, pengelompokan jenis pakan dan pemanfaatan masyarakat setempat. Data yang diperoleh selanjutnya diolah dengan metode tabulasi dan didukung oleh kajian pustaka serta disajikan secara deskriptif untuk menggambarkan kondisi yang terjadi.

\section{HASIL DAN PEMBAHASAN}

\section{A. Komposisi dan Sebaran Jenis}

Burung merupakan jenis satwa yang dapat dijadikan indikator kualitas dalam suatu habitat berdasarkan keragaman jenis yang ditemukan (Hadinoto, Mulyadi, \& Siregar, 2012; Schultze et al., 2004; Walter et al., 2004; Qibtiyah et al., 2013). Komposisi dan keberadaan jenis burung yang ditemukan relatif sedikit atau kurang dalam suatu kawasan, dapat menandakan/ditengarai bahwa habitat yang ada telah terdegradasi atau terfragmentasi. (Reed, 1999) bahwa tingkah laku yang menyebar terbatas atau jarak penyebarannya pendek akan berefek pada penurunan hubungan antara habitat terfragmentasi. Pada kondisi tersebut, spesies akan terikat dengan habitat yang terbatas, tidak mampu bertahan mendapatkan habitat baru, dan bila terjadi perubahan kualitas habitat maka spesies akan mati. Sedangkan bila suatu kawasan hutan yang habitatnya masih utuh atau tidak terganggu oleh aktifitas manusia yang dapat merusak, mempunyai kecenderungan lebih tinggi keragaman jenis satwa yang berada dalam kawasan tersebut. Hal ini diperkuat oleh pendapat (Sudjatnika, Jepson, Soehartono, Crosby, \& Mardiastuti, 1995) serta (Shannaz, Jepson, \& Rudyanto, 1995) yang mengemukakan bahwa burung dengan penyebaran sempit akan mengalami ancaman yang relatif besar dengan menurunnya kualitas dan kuantitas habitat.

Kegiatan penelitian yang dilakukan di kawasan hutan lindung KPHP Sorong Selatan selama 10 (sepuluh) hari efektif pengamatan, telah mendapatkan data dan informasi keanekaragaman burung. Penemuan jenis burung ini merupakan hasil pengamatan di beberapa lokasi pengamatan, yaitu: lokasi hutan Ramsemair, Swamar, Saramtis dan Rebon. Dimana telah ditemukan sedikitnya 34 jenis burung dari 14 famili yang berada di kawasan tersebut (Lampiran 1.).

Sementara itu dari keempat daerah pengamatan yang dilakukan, secara sederhana dapat digambarkan kurva akumulasi jenis burung di daerah tersebut yang disajikan pada Gambar 2.

Kurva penemuan jenis burung menunjukkan hubungan antara daftar list ke-i burung dengan jumlah jenis burung yang ditemukan. Jumlah daftar jenis burung tersebut bertambah sesuai dengan bertambahnya jenis burung yang ditemukan. Kurva penemuan jenis menunjukkan tingkat penemuan keseluruhaan jenis burung yang ada pada suatu kawasan. Pada lokasi Saramtis (Gambar 2.), ditunjukkan penemuan jenis yang tinggi dibandingkan lokasi pengamatan lainnya, hal ini terlihat pada pengamatan hari ke empat hingga hari ke tujuh. 


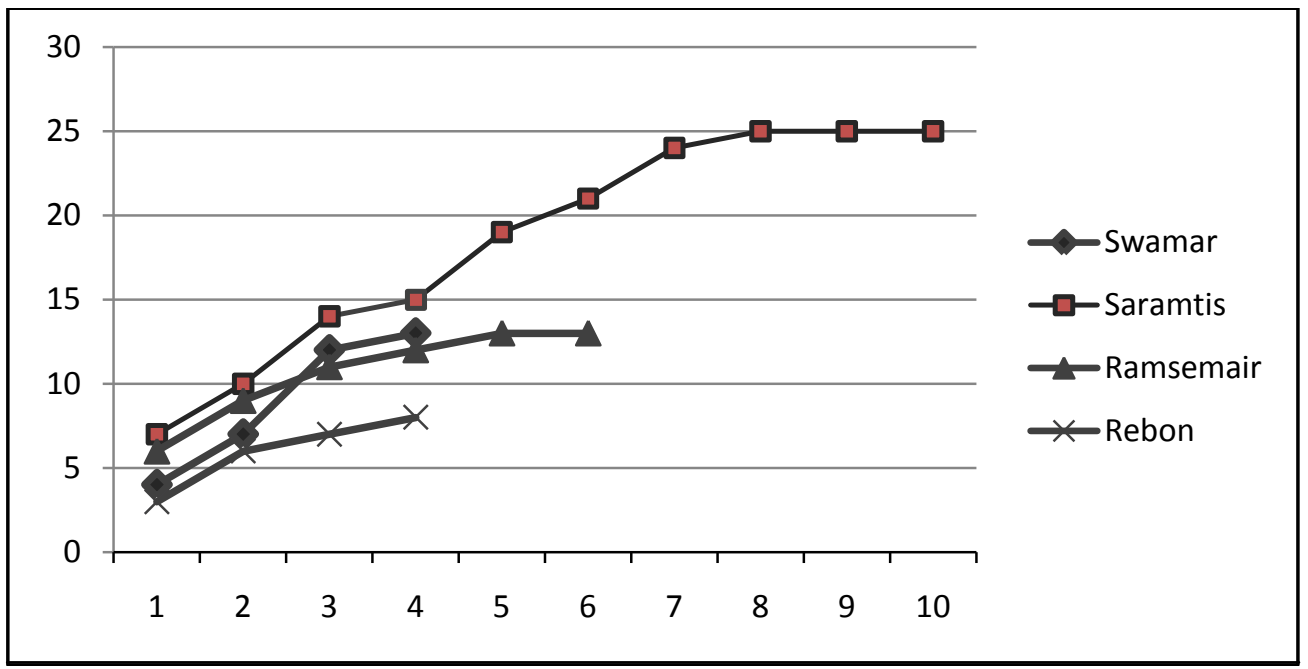

Gambar 2. Kurva akumulasi jenis burung di lokasi pengamatan, di 4 (empat) lokasi KPHP Sorong Selatan

Figure 2. Accumulation of bird species during observation 4 (four) KPHP Sorong South

Namun pengamatan hari ke delapan dan selanjutnya tidak dijumpai lagi penambahan jenis. Hal ini ditunjukkan garis datar, sehingga pada hari selanjutnya tidak dilanjutkan pengamatan. Saramtis merupakan daerah peralihan (edge), dimana adanya batas yang nyata antara hutan primer dengan hutan sekunder (yang terbuka). Hal ini sama yang diungkapkan (Wisnubudi, 2009), keterbukaan tajuk mempengaruhi banyaknya jenis burung yang ditemukan. Habitat yang berbeda berupa sungai dan lahan pertanian mengakibatkan jumlah jenis burung yang ditemukan lebih banyak (Rahayuningsih, Purnomo, \& Priyono, 2010, Odum, 1993; Rahayuningsih, 2010). Sementara pengamatan di Rebon yang merupakan daerah hutan primer, penemuan jenis burung relatif tidak menampakan penambahan jenis. Hal ini menunjukan kurangnya keragaman jenis burung di lokasi ini, sehingga pengamatan diakhiri pada hari ke empat.

\section{B. Habitat dan Komposisi Pakan}

Bentuk habitat yang baik untuk kelangsungan hidup burung adalah habitat yang mampu melindungi dari gangguan maupun menyediakan kebutuhan hidupnya. Pemilihan habitat akan menentukan burung pada lingkungan tertentu (Hadinoto et al., 2012; Latupapua, M., 2011; Partasasmita, 2003). Kondisi topografi di kawasan hutan lindung relatif datar hingga landai. Pengamatan di lokasi Swamar, topografi relatif datar dan ditunjukkan dengan kondisi habtitat yang telah terbuka. Dimana bekas kebun yang telah ditinggalkan dan bekas tebangan tegakan gaharu yang telah diambil.

Beberapa jenis burung yang ditemukan di lokasi pengamatan Ramsemair (lihat Lampiran Tabel 2.), menunjukan bahwa daerah ini masih merupakan hutan primer. Dimana penemuan jenis yang terdapat di daerah ini masih merupakan jenis pemakan buah (umumnya dari kelompok Columbidae). Kondisi hutan dengan tegakan yang cukup rapat dan pakan berupa buah 
alami (hutan) tersedia bagi burung, menjadikan kelompok ini merasa nyaman. Menurut (Renner, Baur, Possler, Winkler., \& Kalkol, 2012), ketersediaan pakan merupakan fungsi dari tipe habitat, pengelolaan hutan oleh pihak pengelola kawasan dan musim. Namun di lokasi pengamatan Swamar (lihat Lampiran Tabel 4.), terlihat beberapa jenis dari kelompok burung pemakan serangga (Rhipidura albolimbata dan Gerygone chloronotus). Pada lokasi ini, adanya bekas pembukaan lahan sebagai tempat berkebun dan nampak adanya tegakan-tegakan yang sengaja ditebang untuk mengambil kayu gaharu. Meskipun sebagai daerah lindung, di kawasan ini masih terlihat masyarakat yang melakukan aktifitas dalam mengolah lahan. Kondisi lahan/daerah yang relatif terbuka merupakan tempat yang digemari oleh beberapa jenis burung pemakan serangga.

Jenis burung relatif mudah ditemukan dan menyukai daerah terbuka umumnya dari jenis pemakan serangga (Setio, Y.O., \& Ginting., 1998). Hal ini kemungkinan adanya sumber pakan berupa serangga yang lebih banyak dijumpai di daerah ini, dibandingkan di lokasi yang lebih rapat tegakannya.

Dari hasil identifikasi dan penemuan jenis di kawasan hutan lindung KPHP Sorong Selatan umumnya merupakan jenis burung dari kelompok tingkatan (strata) hutan $\mathrm{C}$ dan dikategorikan sebagai burung kawasan hutan sekunder. Hal ini nampak (Gambar 3.) terlihat dari jenis yang ditemukan kebanyakan merupakan burung pemakan serangga (insektifora) dari famili Acanthizidae, Rhipiduridae dan Dicruridae. Burung pemakan buah (frugivora) dari famili Columbidae dan Psittacidae). Senada dengan yang dilaporkan (Dewi, Mulyani, \& Santosa, 2007), strata vegetasi III dan IV, pakan burung (buah, bunga, serangga) terdapat dalam jumlah melimpah, sehingga banyak jenis burung yang memanfaatkan strata tersebut. Sementara pada jenis carnivora dari famili Podargidae dan jenis Megapodius freycinet (omnivora) hanya ditemukan pada spot-spot tertentu di kawasan hutan lindung tersebut.

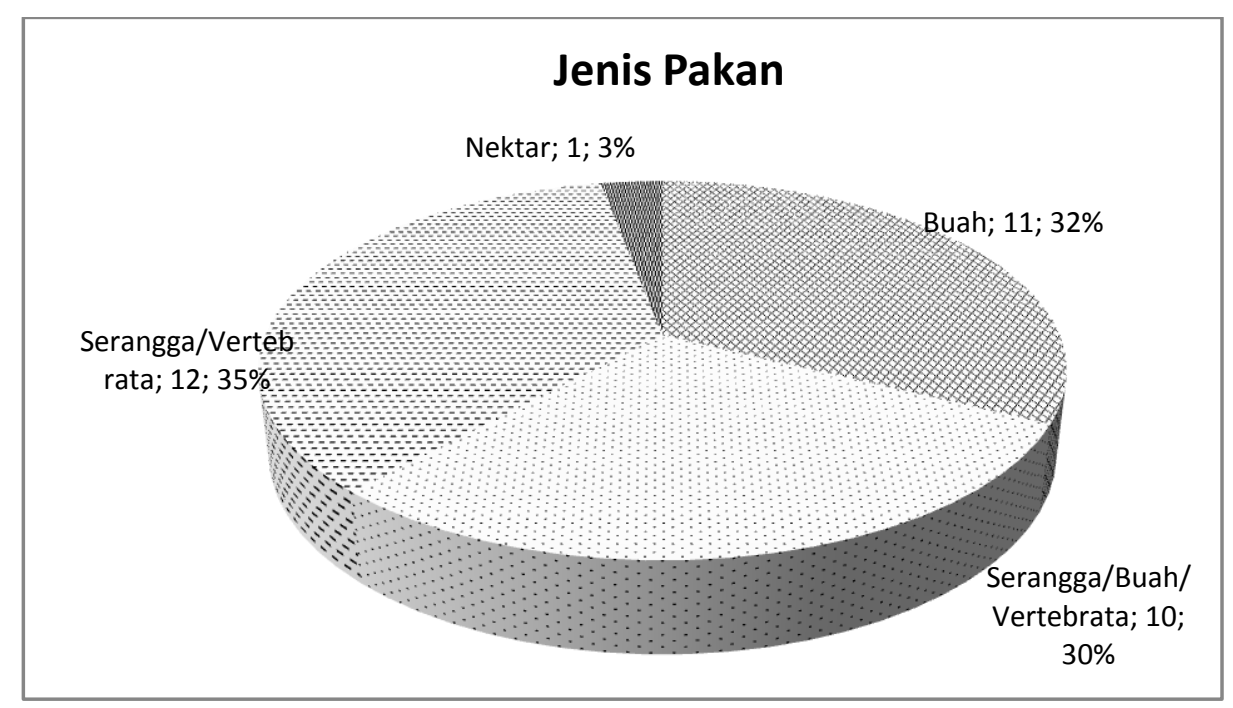

Gambar 3. Komposisi jenis pakan burung

Figure 3. Compotition fiding guild birds 


\section{Pemanfaatan}

Kampung Sesor, merupakan kampung terdekat lokasi pengamatan. Kampung Sesor ini terletak sekitar $37 \mathrm{~km}$ dari kota Kabupaten Teminabuan, Sorong Selatan dan berada di wilayah KPHP Sorong Selatan. Penduduk kampung Sesor berjumlah lebih kurang 20 kepala keluarga (KK) yang merupakan bagian dari masyarakat Distrik Sangguer. Masyarakat peramu, mayoritas penduduk memanfaatkan hutan sebagai mata pencaharian. Hutan digunakan sebagai tempat berkebun, berburu dan mengambil hasil hutan lainnya berupa kayu gaharu. Pada umumnya, masyarakat sekitar hutan seringkali memanfaatkan hasil hutan untuk kebutuhan sehari-hari (Indrawan, Primack, \& Supriatna, 2012) Sementara Hidayatullah \& Saragih (2013) dalam (Saefullah, Mustari, \& Mardistuti, 2015), pemanfaatan hutan yang memperhatikan kelestarian hutan akan menyebabkan hutan tetap lestari dan memberikan hasil yang berkelanjutan. Masyarakat Papua memanfaatkan (ekstraksi) sumber daya alam berupa satwa untuk kepentingan pelaksanaan upacara adat, keperluan acara keagaman yang membutuhkan daging dan untuk memenuhi kebutuhan protein keluarga. Perburuan satwa di area hutan tropis tidak lagi berkelanjutan dan sumberdaya satwa liar sangat rentan terhadap eksploitasi yang berlebihan, sehingga dikhawatirkan dapat menuju kepunahan (Robinson \& Bodmer, 1999; Robinson \& Redfod, 1994). (Mulyawati, 2011), menuliskan perburuan liar dan perusakan hutan/alih fungsi hutan, yang menyebabkan habitat dan kehidupan burung terganggu dan akhirnya punah Prescot-Allen (1982) dalam (Pattiselanno, 2007), sedikitnya ada 62 negara di dunia yang penduduknya memanfaatkan satwa liar sebagai sumber protein hewani melalui kegiatan perburuan. Beberapa jenis satwa memainkan peranan yang sangat penting dan memberikan kontribusi yang sangat signfikan terhadap konsumsi protein hewani di beberapa wilayah Papua. Beberapa satwa yang menjadi incaran masyarakat sebagai upaya pemenuhan protein hewani seperti: rusa (Cervus cervus), babi hutan (Sus scrofa), babi duri (Zaglossus spp.), kasuari (Casuarius sp.) dan maleo (Megapodius sp.). Namun berdasarkan informasi masyarakat, beberapa tahun belakangan ini jenis satwa yang diburu oleh masyarakat tersebut sudah sulit dijumpai. Hal ini kemungkinan disebabkan kondisi hutan lindung yang relatif terbuka, sehingga tempat bermain, mencari makan maupun tempat berlindung bagi sebagian satwa dirasakan kurang nyaman. Kemungkinan lain, adanya perburuan yang dilakukan masyarakat setempat, sehingga jumlah jenis satwa yang produktif (dapat dikonsumsi) melakukan perpindahan untuk mencari tempat yang lebih aman.

Namun berdasarkan penelusuran informasi masyarakat (responden kunci), sebagian besar masyarakat di daerah ini lebih menggantungkan hidupnya dari hasil kebun dibandingkan menjual hasil buruan satwa dari hutan. Hal ini berdasarkan kondisi di lapangan, dimana sangat sulit untuk menjumpai/menemukan satwa yang berukuran besar di kawasan hutan tersebut. Pada jenis tertentu seperti; Megapodius freycinet (maleo/kovat bahasa lokal) merupakan salah satu dari beberapa jenis burung yang menjadi incaran dalam perburuan (personal communication). Jenis ini relatif mudah dijumpai dibandingkan dengan jenis satwa buruan lain sebagai pemenuhan protein bagi masyarakat. 


\section{KESIMPULAN DAN SARAN}

\section{A. Kesimpulan}

1. Hutan Lindung KPHP Sorong Selatan memiliki komposisi dan sebaran jenis burung yang sangat minim.

2. Saramtis yang merupakan daerah peralihan, komposisi dan sebaran jenis relatif lebih tinggi dibandingkan di lokasi lainnya

3. Kelompok dari pemakan serangga dan vertebrata kecil (35\%) lebih besar dibandingkan dari kelompok pemakan lainnya seperti buah (30\%) dan nektar yang hanya $3 \%$.

\section{B. Saran}

Kawasan hutan di KPHP Sorong Selatan perlu dilakukan penataan ulang guna penentuan areal konservasinya. Dimana kawasan hutan lindung yang ditetapkan sangat minim keragaman jenis satwa, khususnya pada satwa burung yang berada di kawasan hutan lindung tersebut.

\section{DAFTAR PUSTAKA}

Behler, T., Pratt, \& Zimwerman, D. A. (2001). Panduan Lapangan BurungBurung di Papua. Jakarta: Puslitbang Biologi LIPI.

Bibby., C., Jones, M., \& Marsden, S. (2000). Teknik-Teknik Ekspedisi Lapangan. In Survey Burung (p. n.a). sine locco: BirdLife International Programme.

Dewi, R. S., Mulyani, Y. A., \& Santosa, Y. (2007). Keanekaragaman Jenis Burung Di Beberapa Tipe Habitat Taman Nasional Gunung Ciremai (Diversity Of Bird Species at Some Habitat Type In Ciremai Mountain National Park). Media Konservasi. Jurnal Ilmiah
Bidang Konservasi Sumberdaya Alam Hayati Dan Lingkungan, 12(3), n.a.

Hadinoto, Mulyadi, A., \& Siregar, Y. I. (2012). Keanekaragaman jenis burung di hutan Kota Pekanbaru. Jurnal Ilmu Lingkungan, 6(1), 25-42.

Hail, C. J., Kavanagh, M., Kumari, K., \& Arifin., I. (1990). Bring Back the Birds (Planning of trees and Other Plants to support Wildlife in Urban Areas). Kuala Lumpur: World Wild Foundation Malaysia.

Howes, J., Bakewell, D., \& Noor, Y. R. (2003). Panduan Studi Burung Pantai. Bogor: Wetlands InternationalIndonesia Programme.

Indrawan, M., Primack, R., \& Supriatna, J. (2012). Biologi Konservasi Edisi Revisi. Jakarta: Yayasan Obor Indonesia.

Jamaksari, H. (2011). Keanekaragaman Burung Pantai Pada Berbagai Tipe Habitat Lahan Basah Di Kawasan Muara Cimanuk, Jawa Barat. Institut Pertanian Bogor.

Kementerian Kehutanan. (2011). Rencana Kehutanan Tingkat Nasional (RKTN) Tahun 2011-2030. Jakarta: Direktorat Perencanaan Kawasan Hutan. Kementerian Kehutanan.

Kementerian Kehutanan. (2013). Kebijakan Pelepasan Kawasan Hutan Produksi Yang Dapat diKonversi (HPK) Untuk Pembangunan Pabrik Gula. Bogor: Kementerian Kehutanan Republik Indonesia.

Latupapua, M., J. J. (2011). Struktur Dan Komposisi Beberapa Jenis Burung Dan 
Nekton Di Mangrove Kawasan Segoro Anak Taman Nasional Alas Purwo. Universitas Gadjah Mada.

Mendidit, A., Gunawan, \& Nurhadi., M. (2003). Komposisi Keanekaragaman Jenis Burung di resort Way Kanan, Taman nasional Way Kambas, Lampung Tengah, Lampung (Laporan Kuliah Kerja Lapangan). Jakarta.

Mulyawati, D. (2011). Pengaruh Ekosistem Terhadap Populasi Burung di Indonesia.

Noerdjito, M., \& Maryanto, I. (2007). JenisJenis Hayati Yang Dilindungi Perundang-Undangan Indonesia. Jakarta: Lembaga Ilmu Pengetahuan Indonesia (LIPI).

Partasasmita, R. (2003). Ekologi burung pemakan buah dan peranannya sebagai penyebar biji. Makalah Falsafah Sains (No. PPs 702). Bogor.

Pattiselanno, F. (2007). Perburuan Kuskus (Phalangeridae) oleh Masyarakat Napan di Pulau Ratewi, Nabire, Papua. Jurnal Biodiversitas, 8(4), 274-278.

Pratiwi, A. (2005). Pengamatan burung di Resort Bama Seksi Konservasi Wilayah II Bekol dalam Upaya Reinventarisasi Potensi Jenis. sine locco.

Rahayuningsih, M., Purnomo, F. A., \& Priyono, B. (2010). Keanekaragaman Burung di Desa Karangasem Kecamatan Wirosari Kabupaten Grobogan Jawa Tengah. Biosaintifika, 2(2), 82-89.

Reed, J. M. (1999). The Role of Behavior in Recent Avian Extinctions and Endangerements. Conservation Biology,
13(2), 232-241.

Renner, S., Baur, S., Possler, A., Winkler., J., \& Kalkol, E. K. V. (2012). Food preferences of winter bird communities in different forest types. PLoS ONE, 7(12), 1-10. https://doi.org/10.1371/ journal.pone. 0053121.

Rizal, A., HB., I., Dewi, N., \& Sumedi., P. (2011). Kajian Strategi Implementasi Kesatuan Pengelolaan Hutan (KPH): Studi Kasus di Kabupaten Tana Toraja, Provinsi Sulawesi Selatan. Jurnal Analisis Kebijakan Kehutanan, 8(2), 167-188.

Robinson, J. G., \& Bodmer, R. (1999). Towards Wildlife Management in Tropical Forest. Journal of Wildlife Management, 63, 1-13.

Robinson, J. G., \& Redfod, K. (1994). Measuring the sustainability of hunting tropical forest. Oryx, 28, 249-256.

Saefullah, A., Mustari, A. H., \& Mardistuti, A. (2015). Keanekaragaman Jenis Burung Pada Berbagai Tipe Habitat Beserta Gangguannya Di Hutan Penelitian Dramaga, Bogor, Jawa Barat. Media Konservasi, 20(2), 117-124.

Sawitri, R., \& Subiandono, E. (2011). Karakteristik dan Persepsi Masyarakat Daerah Penyangga Taman Nasional Gunung Halimun Salak. Jurnal Penelitian Hutan Dan Konservasi Alam, 8(3), 273-285.

Schultze, C., Waltert, M., Kess-ler, P. J., Pitopang, R., Shahabuddin, Veddeler, D., \& Tscharntke, T. (2004). Biodiversity Indicator Groups of Tropical Land Use Systems: Comparing 
Plants, Birds, and In-sects. Ecological Applications, 14(5), 1321-1333.

Setio, P., Y.O., L., \& Ginting., J. (1998). Habitat and Population of Lesser Bird of Paradise (Paradisea minor jobiensis Rothschild) and Traditional Conservation Management at Barawai, Yapen Timur. Buletin Penelitian Kehutanan Manokwari, n.a, n.a.

Shannaz, J., Jepson, P., \& Rudyanto. (1995). Burung-burung Terancam Punah di Indonesia. Bogor: PHPA/Birdlife International-Indonesia Programme.

Sudjatnika, P., Jepson, T. R., Soehartono, M., Crosby, J., \& Mardiastuti, A. (1995). Melestarikan Keanekaragaman Hayati Indonesia Pendekatan Daerah Burung
Endemik. Jakarta: PHPA/Birdlife International-Indonesia Programme.

Sukmantoro, W., Irham, M., Novarino, W., Hasudungan, F., Kemp, N., \& Muchtar, M. (2007). Daftar Burung Indonesia Nomor 2. Bogor: Indonesian Ornithologists Union.

Welty, J. C. (1982). The life of Birds. Philadelphia: Saunders College Publising.

Wisnubudi, G. (2009). Penggunaan strata vegetasi oleh burung di kawasan wisata Taman Nasioanal Gunung HalimunSalak. Visi Vitalis, 2(2), 41-49. 


\section{Lampiran}

Tabel 1. Nama daerah, famili dan jenis pakan burung

Table 1. Local name, family and fiding guild

\begin{tabular}{|c|c|c|c|c|c|}
\hline NO & $\begin{array}{c}\text { Nama } \\
\text { Daerah }\end{array}$ & Nama Umum & Nama Latin & Famili & Pakan \\
\hline 1 & Moswet & Walik wompu & Ptilinopus magnificus & Columbidae & Buah \\
\hline 2 & Hik & Walik dada-putih & Ptilinopus ornatus & Columbidae & Buah \\
\hline 3 & Habe & Pergam ekor-ungu & Ducula rufigaster & Columbidae & Buah \\
\hline 4 & Habe & Pergam pinon & Ducula pinon & Columbidae & Buah \\
\hline 5 & Yobo & Uncal besar & $\begin{array}{l}\text { Reinwardtoena } \\
\text { reinwartii }\end{array}$ & Columbidae & Buah \\
\hline 6 & Kalehes & Perkici pelangi & $\begin{array}{l}\text { Trichoglossus } \\
\text { haematodus }\end{array}$ & Psittacidae & Buah \\
\hline 7 & Wer & Kasturi kepala-hitam & Lorius lory & Psittacidae & Buah \\
\hline 8 & But & Nuri bayan & Eclectus roratus & Psittacidae & Buah \\
\hline 9 & Awet & Kakatua galerita & Cacatua galerita & Psittacidae & Buah \\
\hline 10 & Weak & Kakatua raja & Probosciger aterrimus & Psittacidae & Buah \\
\hline 11 & Wokdif & Nuri-ara desmarest & $\begin{array}{l}\text { Psittaculirostris } \\
\text { desmarestii }\end{array}$ & Psittacidae & Buah \\
\hline 12 & Arit & Cekakak-pita biasa & Tanysiptera galatea & Alcedinidae & Serangga/vertebrata kecil \\
\hline 13 & Sangger & Srigunting lencana & Dicrurus hottentottus & Alcedinidae & Serangga/vertebrata kecil \\
\hline 14 & Unau & Perling ungu & Aplonis metallica & Alcedinidae & Serangga/vertebrata kecil \\
\hline 15 & Kororo & Cekakak rimba & Halcyon macleayii & Alcedinidae & Serangga/vertebrata kecil \\
\hline 16 & Kororo & Kukabura perut-merah & Dacelo gaudichaud & Alcedinidae & Serangga/vertebrata kecil \\
\hline 17 & Wamoh & Julang papua & Aceros plicatus & Buceroidae & Buah/vertebrata kecil \\
\hline 18 & Komi & Paruh-kodok papua & Podargus papuensis & Strigidae & Serangga/vertebrata kecil \\
\hline 19 & Kontef & Cikukua tanduk & Philemon buceroides & Meliphagidae & $\begin{array}{l}\text { Serangga/Buah/vertebrata } \\
\text { kecil }\end{array}$ \\
\hline 20 & Katuak & Kepudang-sungu hitam & Coracina melaena & Campephagidae & $\begin{array}{l}\text { Serangga/Buah/vertebrata } \\
\text { kecil }\end{array}$ \\
\hline 21 & Sikomak & Sericornis vogelkop & Sericornis rufescens & Acanthizidae & Serangga/vertebrata kecil \\
\hline 22 & Sikomak & Sericornis papua & Sericornis papuensis & Acanthizidae & Serangga/vertebrata kecil \\
\hline 23 & Petahain & Remetuk tunggir-hijau & Gerygone chloronotus & Acanthizidae & Serangga/vertebrata kecil \\
\hline 24 & Sangger & Kipasan ramah & Rhipidura albolimbata & Rhipiduridae & Serangga/vertebrata kecil \\
\hline 25 & Sangger & Kipasan kebun & Rhipidura leuconphrys & Rhipiduridae & Serangga/vertebrata kecil \\
\hline 26 & Woyu & Kehicap bertopi & Monarcha manadensis & Rhipiduridae & Serangga/vertebrata kecil \\
\hline 27 & Wereh & Mino muka-kuning & Mino dumontii & Sturnidae & $\begin{array}{l}\text { Serangga/Buah/vertebrata } \\
\text { kecil }\end{array}$ \\
\hline 28 & Sangger & Srigunting lencana & Dicrurus hottentottus & Sturnidae & $\begin{array}{l}\text { Serangga/Buah/vertebrata } \\
\text { kecil }\end{array}$ \\
\hline 29 & Unau & Perling ungu & Aplonis metallica & Sturnidae & $\begin{array}{l}\text { Serangga/Buah/vertebrata } \\
\text { kecil }\end{array}$ \\
\hline 30 & Woi & Bubut hitam & Centropus bernsteini & Cuculidae & $\begin{array}{l}\text { Serangga/Buah/vertebrata } \\
\text { kecil }\end{array}$ \\
\hline 31 & Vevak & Cikrak-peri paruh-lebar & Malurus grayi & Maluridae & $\begin{array}{l}\text { Serangga/Buah/vertebrata } \\
\text { kecil }\end{array}$ \\
\hline 32 & Woyu & Kehicap bertopi & Monarcha manadensis & Myiagridae & $\begin{array}{l}\text { Serangga/Buah/vertebrata } \\
\text { kecil }\end{array}$ \\
\hline 33 & Kovat & Gosong kelam & Megapodius freycinet & Megapodiidae & $\begin{array}{l}\text { Serangga/Buah/vertebrata } \\
\text { kecil }\end{array}$ \\
\hline 34 & Soet & $\begin{array}{l}\text { Isap-madu paruh- } \\
\text { panjang }\end{array}$ & $\begin{array}{l}\text { Melilestes } \\
\text { megarhynchus }\end{array}$ & Nectariniidae & 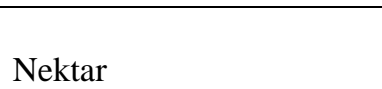 \\
\hline
\end{tabular}


Tabel 2. Jenis-jenis burung di daerah Ramsemair di kawasan Lindung KPH Sorong Selatan Table 2. Birds in area Ramsemair on Protected area on KPH Sorong South

\begin{tabular}{cllll}
\hline No & Bahasa Lokal & \multicolumn{1}{c}{ Nama Umum } & Nama Latin & \multicolumn{1}{c}{ Famili } \\
\hline 1 & Kovat & Gosong kelam (ras affinis) & Megapodius freycinet & Megapodiidae \\
\hline 2 & Moswet & Walik wompu & Ptilinopus magnificus & Columbidae \\
\hline 3 & Hik & Walik dada-putih & Ptilinopus ornatus & Columbidae \\
\hline 4 & Safok & Walik perut-jingga & Ptilinopus iozonus & Columbidae \\
\hline 5 & Habe & Pergam pinon & Ducula pinon & Columbidae \\
\hline 6 & Habe & Pergam ekor-ungu & Ducula rufigaster & Columbidae \\
\hline 7 & Sekemit & Merpati-gunung papua & Gymnophaps albertisii & Columbidae \\
\hline 8 & Kalehes & Perkici pipi-merah & Charmosyna rubrigularis & Psittacidae \\
\hline 9 & Kalehes & Perkici pelangi & Trichoglossus & Psittacidae \\
\hline 10 & Wer & Kasturi kepala-hitam & Lorius lory & Psittacidae \\
\hline 11 & But & Nuri bayan & Eclectus roratus & Psittacidae \\
\hline 12 & Awet & Kakatua galerita & Cacatua galerita & Psittacidae \\
\hline 13 & Kontef & Cikukua tanduk & Philemon buceroides & Meliphagidae \\
\hline
\end{tabular}

Tabel 3. Jenis-jenis burung di daerah Saramtis di kawasan Lindung KPH Sorong Selatan Table 3. Birds in area Saramtis on Protected area on KPH Sorong South

\begin{tabular}{|c|c|c|c|c|}
\hline No. & Nama Daerah & Nama Umum & Nama Latin & Famili \\
\hline 1 & Moswet & Walik wompu & Ptilinopus magnificus & Columbidae \\
\hline 2 & Habe & Pergam pinon & Ducula pinon & Columbidae \\
\hline 3 & Habe & Pergam ekor-ungu & Ducula rufigaster & Columbidae \\
\hline 4 & Yobo & Uncal besar & Reinwardtoena reinwartii & Columbidae \\
\hline 5 & Kalehes & Perkici pelangi & Trichoglossus haematodus & Psittacidae \\
\hline 6 & Wer & Kasturi kepala-hitam & Lorius lory & Psittacidae \\
\hline 7 & But & Nuri bayan & Eclectus roratus & Psittacidae \\
\hline 8 & Awet & Kakatua galerita & Cacatua galerita & Psittacidae \\
\hline 9 & Weak & Kakatua raja & Probosciger aterrimus & Psittacidae \\
\hline 10 & Wokdif & Nuri-ara desmarest & Psittaculirostris desmarestii & Psittacidae \\
\hline 11 & Kororo & Kukabura perut-merah & Dacelo gaudichaud & Alcedinidae \\
\hline 12 & Wamoh & Julang papua & Aceros plicatus & Buceroidae \\
\hline 13 & Komi & Paruh-kodok papua & Podargus papuensis & Strigidae \\
\hline 14 & Kontef & Cikukua tanduk & Philemon buceroides & Meliphagidae \\
\hline 15 & Katuak & Kepudang-sungu hitam & Coracina melaena & Campephagidae \\
\hline 16 & Sikomak & Sericornis vogelkop & Sericornis rufescens & Acanthizidae \\
\hline 17 & Sikomak & Sericornis papua & Sericornis papuensis & Acanthizidae \\
\hline 18 & Petahain & Remetuk tunggir-hijau & Gerygone chloronotus & Acanthizidae \\
\hline 19 & Sangger & Kipasan ramah & Rhipidura albolimbata & Rhipiduridae \\
\hline 20 & Sangger & Kipasan kebun & Rhipidura leuconphrys & Rhipiduridae \\
\hline 21 & Woyu & Kehicap bertopi & Monarcha manadensis & Rhipiduridae \\
\hline 22 & Wereh & Mino muka-kuning & Mino dumontii & Sturnidae \\
\hline
\end{tabular}




\begin{tabular}{cllll}
\hline No. & Nama Daerah & \multicolumn{1}{c}{ Nama Umum } & \multicolumn{1}{c}{ Nama Latin } & Famili \\
\hline 23 & Sangger & Srigunting lencana & Dicrurus hottentottus & Sturnidae \\
\hline 24 & Unau & Perling ungu & Aplonis metallica & Sturnidae \\
\hline 25 & Woi & Bubut hitam & Centropus bernsteini & Cuculidae \\
\hline
\end{tabular}

Tabel 4. Jenis-jenis burung di daerah Swamar di kawasan Lindung KPH Sorong Selatan Table 4. Birds in area Swamar on Protected area on KPH Sorong South

\begin{tabular}{cllll}
\hline No. & Nama Daerah & \multicolumn{1}{c}{ Nama Umum } & \multicolumn{1}{c}{ Nama Latin } & \multicolumn{1}{c}{ Famili } \\
\hline 1 & Moswet & Walik wompu & Ptilinopus magnificus & Columbidae \\
\hline 2 & Habe & Pergam pinon & Ducula pinon & Columbidae \\
\hline 3 & Sikomak & Sericornis papua & Sericornis papuensis & Acanthizidae \\
\hline 4 & Petahain & Remetuk tunggir-hijau & Gerygone chloronotus & Acanthizidae \\
\hline 5 & Vevak & Cikrak-peri paruh-lebar & Malurus grayi & Maluridae \\
\hline 6 & Woyu & Kehicap bertopi & Monarcha manadensis & Myiagridae \\
\hline 7 & Sangger & Kipasan ramah & Rhipidura albolimbata & Rhipiduridae \\
\hline 8 & Sangger & Kipasan kebun & Rhipidura leuconphrys & Rhipiduridae \\
\hline 9 & Soet & Isap-madu paruh-panjang & Melilestes megarhynchus & Nectariniidae \\
\hline 10 & Kontef & Cikukua tanduk & Philemon buceroides & Meliphagidae \\
\hline 11 & Sangger & Srigunting lencana & Dicrurus hottentottus & Alcedinidae \\
\hline 12 & Unau & Perling ungu & Aplonis metallica & Alcedinidae \\
\hline 13 & Arit & Cekakak-pita biasa & Tanysiptera galatea & Alcedinidae \\
\hline
\end{tabular}

Tabel 5. Jenis-jenis burung di daerah Rebon di kawasan Lindung KPH Sorong Selatan Table 5. Birds in area Rebon on Protected area on KPH Sorong South

\begin{tabular}{cllll}
\hline No. & Nama Daerah & \multicolumn{1}{c}{ Nama Umum } & \multicolumn{1}{c}{ Nama Latin } & \multicolumn{1}{c}{ Famili } \\
\hline 1 & Kovat & Gosong kelam & Megapodius freycinet & Megapodiidae \\
\hline 2 & Moswet & Walik wompu & Ptilinopus magnificus & Columbidae \\
\hline 3 & Komi & Paruh-kodok papua & Podargus papuensis & Columbidae \\
\hline 4 & Sikomak & Sericornis papua & Sericornis papuensis & Acanthizidae \\
\hline 5 & Kontef & Cikukua tanduk & Philemon buceroides & Meliphagidae \\
\hline 6 & Sangger & Srigunting lencana & Dicrurus hottentottus & Dicruridae \\
\hline 7 & Unau & Perling ungu & Aplonis metallica & Sturnidae \\
\hline 8 & Kororo & Cekakak rimba & Halcyon macleayii & Alcedinidae \\
\hline
\end{tabular}


Jurnal FALOAK Vol. 2 N0.1 April 2018: 57 -70 